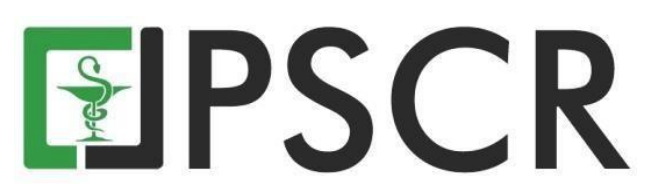

\title{
Standardisasi Simplisia dan Ekstrak Buah Kemukus (Piper cubeba Lf.) Sebagai Bahan Baku Sediaan Kapsul Jamu Sesak Nafas
}

\author{
Indrawati Kurnia Setyani1, ${ }^{1,2}$, Wahyono ${ }^{3}$ dan Teuku Nanda Saifullah Sulaiman ${ }^{4 *}$ \\ ${ }^{1}$ Program Studi Magister Ilmu Farmasi Fakultas Farmasi, Universitas Gadjah Mada, J1. Sekip Utara, Sleman, \\ Yogyakarta, Indonesia, 55281. \\ ${ }^{2}$ PT Swayasa Prakarsa, Jl. Cik Di Tiro No 34, Yogyakarta, Indonesia, 55223. \\ ${ }^{3}$ Departemen Biologi Farmasi Fakultas Farmasi Universitas Gadjah Mada, Jl. Sekip Utara, Sleman, Yogyakarta, \\ Indonesia, 55281. \\ ${ }^{4}$ Departemen Farmasetika Fakultas Farmasi Universitas Gadjah Mada, Jl. Sekip Utara, Sleman, Yogyakarta, \\ Indonesia, 55281. \\ *email korespondensi: th_saifullah@ugm.ac.id
}

Received 13 April 2021, Accepted 28 June 2021, Published 15 November 2021

\begin{abstract}
Abstrak: Standardisasi merupakan suatu upaya untuk menjaga kualitas bahan baku yang berasal dari tanaman. Standardisasi meliputi parameter spesifik dan non spesifik. Kubebin merupakan senyawa utama yang terkandung di dalam buah kemukus (Piper cubeba Lf.). Senyawa ini bisa digunakan sebagai marker untuk mengendalikan kualitas kemukus. Perbedaan tempat tumbuh memberi pengaruh terhadap variasi kadar kubebin. Penelitian ini bertujuan untuk melakukan standardisasi dan membandingkan kadar kubebin dari tiga daerah yang berbeda yaitu Kulonprogo, Magelang, dan Wonosobo sebagai bahan baku untuk pembuatan sediaan kapsul jamu sesak nafas. Kemukus diekstrak dengan metode maserasi. Kadar kubebin merupakan parameter utama dalam pemilihan sumber bahan baku. Penetapan kadar kubebin dengan metode kromatografi lapis tipis-densitometri. Simplisia dengan kadar kubebin yang tertinggi selanjutnya dilakukan standardisasi. Standardisasi simplisia meliputi penetapan kadar air, kadar minyak atsiri, susut pengeringan, kadar abu, kadar abu tak larut asam, cemaran logam berat, residu pestisida dan aflatoksin total. Standardisasi mikrobiologi ekstrak meliputi angka kapang/ khamir, angka lempeng total, mikroba patogen (Escerichia coli, Staphylococcus aureus, Pseudomonas aeruginosa, Salmonella $s p$ dan Shigella sp). Perbedaan tempat tumbuh tidak berpengaruh terhadap kadar kubebin di dalam ekstrak tetapi berpengaruh terhadap randemen. Proses granulasi tidak memberikan pengaruh yang bermakna terhadap senyawa kubebin. Hasil standardisasi kemukus dari Wonosobo menunjukkan bahwa parameter non-spesifik untuk simplisia dan ekstrak memenuhi persyaratan bahan baku obat tradisional sesuai acuan standar WHO Guidelines dan Farmakope Herbal Indonesia.
\end{abstract}

Kata kunci: granul; kemukus; kubebin; standardisasi

\begin{abstract}
Standardization of Simplicia and Extract of Kemukus Fruit (Piper cubeba Lf.) as Raw Materials for Shortness of Breath for Herbal Medicine Capsules. Standardization is an effort to maintain the quality of raw materials derived from plants. Standardization includes specific and non-specific parameters. Cubebin is the main compound found in cubeb fruit (Piper cubeba Lf.) that has been used as a marker to control the quality of cubeb simplisia. The difference in the place of growth affects the variation in the levels of cubebin. This study aimed to standardize and compare the levels of cubebin from three different regions, namely Kulonprogo, Magelang, and Wonosobo as raw materials for making shortness of breath herbal capsules. The cubes were extracted by the maceration method. Cubebin content is the main parameter in selecting the source of raw materials. Determination of the levels of cubebin by the thin layer chromatography-densitometry method. Herbs with the highest levels of cubebin were then standardized. Herbs standardization includes
\end{abstract}


determination of water content, essential oil content, drying loss, ash content, acid insoluble ash content, heavy metal contamination, total pesticide residues, and aflatoxins. The microbiological standardization of the extract included mold/yeast numbers, total plate count, pathogenic microbes (Escherichia coli, Staphylococcus aureus, Pseudomonas aeruginosa, Salmonella $s p$, and Shigella sp). The difference in the place of growth had no effect on the content of cubebin in the extract, but it had an effect on yield and the granulation process had no effect on the cubebin compound. The results of standardization of cubeb from Wonosobo show that non-specific parameters for herbs and extract meet the raw material requirements for traditional medicines according to the standard reference of the WHO Guidelines and Indonesian Herbal Pharmacopoeia.

Keywords: granules; cubeb; cubebin; standardization

\section{Pendahuluan}

Indonesia merupakan negara yang kaya akan sumber daya hayati baik tanaman asli maupun bukan tanaman asli (Cahyaningsih et al., 2021). Salah satu tanaman asli Indonesia adalah Kemukus (Piper cubeba L.f) dari famili Piperaceae (Lim, 2012). Tanaman ini banyak terdapat di pulau Jawa, Sumatra dan sebagian Kalimantan selatan (Alqadeeri et al., 2019) yang kemudian menyebar ke Malaysia dan Srilanka (Lim, 2012). Kemukus sudah lama dimanfaatkan untuk pengobatan terutama oleh masyarakat jawa seperti yang tertulis pada naskah pengobatan kuno yaitu buku Serat Primbon Jampi Jawi yang diterbitkan tahun 1928 oleh keraton Surakarta Hadiningrat (Makmun et al., 2014).

Penelitian terkait aktivitas farmakologis yang pernah dilaporkan antara lain sebagai agen profilaksis, antioksidan, hepatoprotektif, insektisida dan acarisida, anti mikroba, anti amoba, anti diabetes, hipokolesterol, analgetik, imunomodulator, anti inflamasi, anti kanker, anti depresan, anti ulkus, efek pada sistem kardiovaskular, efek pada sistem pernafasan (Ahmad et al., 2020). Senyawa utama yang terkandung di dalam kemukus adalah golongan lignan, lignan yang berhasil diisolasi dari ekstrak etanolik antara lain kubebin, yatein, dihidroclusin, clusin, haplomirfolin, veratraldehid (Arruda et al., 2019). Kemukus memiliki aroma yang kuat, aroma tersebut berasal dari minyak atsiri yang terkandung di dalam biji antara lain hidrokarbon sesquiterpen, $\beta$-kariofilen, $\delta$-sadinen, $\alpha$ dan $\beta$-cubeben serta sejumlah kecil monoterpen (Salehi et al., 2019).

Kemukus banyak digunakan oleh industri obat tradisional sebagai komponen jamu untuk sesak nafas (Wahyono, 2005). Bahan baku herbal diperoleh dari tanaman budidaya dan tanaman liar, namun sebagian besar pengadaannya diambil dari tanaman liar dari berbagai tempat yang berbeda, sedangkan tanaman herbal yang digunakan dari hasil budidaya masih terbatas. Perbedaan lokasi tumbuh tanaman menyebabkan variasi kandungan zat aktif. Terjadinya variasi pada kandungan zat aktif menjadi salah satu faktor penting untuk proses standardisasi (Lubbe \& Verpoorte, 2011). Kebutuhan industri akan bahan baku herbal 
semakin meningkat (Balekundri \& Mannur, 2020), menyebabkan standardisasi menjadi tahapan yang penting dalam pengembangan obat bahan alam untuk memperoleh konsistensi profil kimia, aktivitas biologis, serta quality assurance pada tahapan produksinya (Bajpai, 2012). Pada penelitian ini, kadar kubebin digunakan sebagai merupakan parameter utama dalam pemilihan sumber bahan baku, sebab standardisasi yang mengacu pada senyawa marker menjadi hal yang sangat penting untuk menilai kualitas produk obat bahan alam dalam memberikan gambaran fitokonstituen serta untuk memantau keajegan bets ke bets produk akhir (Gaonkar et al., 2020), kadar kubebin ditetapkan dengan kromatografi lapis tipis (KLT) densitometri karena teknik ini bisa digunakan untuk mengidentifikasi senyawa marker (Masoodi et al., 2021). Buah kemukus dengan kadar kubebin yang tertinggi selanjutnya dilakukan standardisasi non spesifik mengacu pada Farmakope Herbal Indonesia dan WHO Guidelines. Sediaan kapsul merupakan bentuk sediaan yang paling feasibel dalam memformulasikan suatu bahan aktif dari ekstrak. Tingkat kemudahan dan kepraktisan dalam formulasi sediaan kapsul menjadi pilihan utama dalam merancang sediaan kapsul herbal kemukus. Penelitian terkait standarisasi ekstrak buah kemukus yang diformulasikan ke dalam sediaan kapsul belum pernah dilaporkan sampai saat ini. Penelitian ini bertujuan untuk mengetahui pengaruh perbedaan tempat tumbuh terhadap randemen ekstrak dan kadar senyawa kubebin. Selain itu juga untuk menetapkan standardisasi parameter spesifik dan nonspesifik dari ekstrak dengan kadar kubebin tertinggi sebagai bahan baku untuk pembuatan sediaan kapsul jamu sesak nafas.

\section{Bahan dan Metode}

\subsection{Bahan}

Bahan yang digunakan dalam penelitian ini adalah buah kemukus yang diambil dari tiga daerah yaitu Kulonprogo, Magelang, dan Wonosobo. Etanol teknis 70\% diperoleh dari pemasok lokal (General Labora, Yogyakarta Indonesia) digunakan untuk proses ekstraksi. Plat KLT silica gel 60 GF $_{254}$, diklorometana, toluene, etil asetat, dan asam sulfat diperoleh dari Merck (Darmstadt, Jerman). Standar kubebin diperoleh dari Extrasynthese (Genay, Perancis). Fumed silica (Aerosil SH200), amilum sagu, dan cangkang kapsul berderajat farmasetis dibeli dari supplier local (General Labora, Yogyakarta Indonesia).

\subsection{Metode}

\subsubsection{Identifikasi tanaman secara makroskopi}

Identifikasi tanaman dilakukan secara makroskopi meliputi ukuran, warna, karakteristik permukaan, tekstur, bau, dan rasa pada simplisia buah kemukus (World Health Organization, 2011). 


\subsubsection{Pembuatan ekstrak}

Metode pembuatan ekstrak mengacu pada Farmakope Herbal Indonesia (Kementerian Kesehatan RI, 2017). Ekstrak dari masing-masing tempat tumbuh yang berbeda dibuat secara terpisah dengan metode maserasi. Cairan penyari yang digunakan adalah etanol $70 \%$ dengan perbandingan 10:1 terhadap bahan. Proses maserasi dilakukan selama 1x24 jam kemudian diikuti dengan proses remaserasi dengan perbandingan pelarut dan waktu/lama perendaman yang sama. Ekstrak kemudian dipekatkan menggunakan rotary evaporator sehingga diperoleh ekstrak kental. Ekstrak yang diperoleh kemudian ditentukan kadar kubebin dan distandarisasi sebelum diformulasikan ke dalam sediaan granul.

2.2.3. Penetapan kadar kubebin ekstrak kemukus dari Kulonprogo, Magelang, dan Wonosobo

Penetapan kadar kubebin dilakukan dengan menggunakan kromatografi lapis tipisdensitometri. Fase diam yang digunakan adalah silika gel $\mathrm{GF}_{254}$ sedangkan fase gerak adalah diklorometana:etil asetat (8:2). Deteksi yang digunakan $\mathrm{UV}_{254}, \mathrm{UV}_{366}$ dan pereaksi penampak bercak $\mathrm{H}_{2} \mathrm{SO}_{4}$ etanolik (Wagner \& Bladt, 1996; Wahyono, 2005). Penotolan dilakukan dengan alat Linomat Camag 5 Auto Applier sebanyaj $5 \mu \mathrm{L}$ untuk ekstrak dan beberapa seri konsentrasi kubebin $(10 \mu \mathrm{g} / \mu \mathrm{L})$ dengan volume 1, 2, 4, 6, 8, dan $10 \mu \mathrm{L}$. Setelah proses elusi, plat KLT dipindai menggunakan Camag 3 densitometer (Tokyo, Jepang) pada panjang gelombang $289 \mathrm{~nm}$. Kurva kalibrasi antara jumlah kubebin dan luas puncak dianalisis menggunakan analisa regresi linear sederhana digunakan untuk penetapan kadar kubebin dalam sampel buah kemukus. Penetapan spesifitas, batas deteksi minimal, presisi dan penetapan kadar kubebin mengacu pada penelitian sebelumnya (Pillai \& Pandita, 2016). Hasil penetapan kadar kubebin dari tiga tempat tumbuh dengan kadar tertinggi selanjutnya dilakukan standardisasi non spesifik pada simplisia dan ekstrak buah kemukus.

\subsubsection{Standardisasi simplisia kemukus}

Standarisasi simplisia kemukus dilakukan dengan beberapa parameter yaitu susut pengeringan, kadar air, kadar abu, kadar abu tak larut asam, cemaran logam berat, residu pestisida, dan aflatoksin total.

- Susut pengeringan

Sampel sejumlah 1gram diletakkan pada wadah sampel yang terdapat di dalam alat OHAUS MB-01 moisture analyzer balance (Sanghai, Tiongkok). Alat dinyalakan suhu diatur $105^{\circ} \mathrm{C}$, lalu ditunggu sampai bobot tetap. Angka yang muncul dinyatakan sebagai persentase bobot yang hilang merupakan hasil susut pengeringan (World Health Organization, 2011) 
- Kadar air

Sampel yang digunakan sebanyak 5 gram dimasukkan ke dalam alat destilasi toluen. Volume air yang terukur dibaca setelah toluen dan air memisah secara sempurna. Kadar air dihitung sebagai volume dalam bobot dengan nilai tidak lebih dari $10 \%$ (Kementerian Kesehatan RI, 2017).

- Kadar abu

Sampel ditimbang sebanyak 2 gram, kemudian dimasukkan ke dalam krus silikat yang telah dipijarkan dan ditara. Krus dipijarkan sampai arang habis kemudian didinginkan dan ditimbang. Kadar abu dihitung terhadap bahan yang telah dikeringkan di udara (World Health Organization, 2011)

- Kadar abu tak larut asam

Abu yang diperoleh dari penetapan kadar abu didihkan dengan $25 \mathrm{~mL}$ asam sulfat encer $\mathrm{P}$ selama 5 menit. Bagian yang tidak larut asam dikumpulkan dan disaring melalui kertas saring bebas abu, kemudian dicuci dengan air panas. Hasil cucian kemudian dipijarkan sampai bobot konstan lalu ditimbang. Kadar abu yang tidak larut asam dihitung terhadap bahan yang telah dikeringkan di udara (World Health Organization, 2011).

- Cemaran logam berat

Penetapan kadar logam berat meliputi Merkuri $(\mathrm{Hg})$, Timbal $(\mathrm{Pb})$, Cadmium $(\mathrm{Cd})$ dan Arsen (As) menggunakan instrumen spektroksopi serapan atom (The United States Pharmacopeial Convention, 2017).

- Residu pestisida

Penetapan residu pestisida dilakukan terhadap golongan organoklor dan organofosfat menggunakan instrumen kromatografi gas-spektroskopi massa. Sebanyak 10 jenis kontaminan yang dianalisis antara lain Oxychlordane, DDT, Gamma-BHC, Endosulfan II, Heptachlor, Aldrin, Hexachrolbenzen, Chlorothalonil, 4,4-DDE dan 4,4 DDT (Reynolds, 2019).

- Aflatoksin total

Penetapan aflatoksin total (B1, B2, G1 dan G2) menggunakan instrumen LC-MS/MS (Bessaire et al., 2019).

\subsubsection{Standardisasi ekstrak kemukus}

Standardisasi terhadap ekstrak dilakukan setelah hasil standardisasi pada simplisia kemukus memenuhi persyaratan. Adapun pengujian yang dilakukan antara lain :

- Kadar air

Sampel yang digunakan sebanyak 5 gram dimasukkan ke dalam alat destilasi toluen. Volume air yang terukur dibaca setelah toluen dan air memisah secara sempurna. Kadar air 
dihitung sebagai volume dalam bobot dengan nilai tidak lebih dari 10\% (Kementerian Kesehatan RI, 2017)

- Kadar Minyak Atsiri

Penetapan kadar minyak astiri menggunakan alat destilasi. Metode uji mengacu pada Farmakope Herbal Indonesia (Kementerian Kesehatan RI, 2017).

- Cemaran mikroba

Penetapan cemaran mikroba mengacu pada WHO Guidelines (World Health Organization, 2011) meliputi uji angka kapang khamir (AKK), angka lempeng total (ALT) dan Uji Mikroba patogen (Escerichia coli, Staphylococcus aureus, Pseudomonas aeruginosa, Salmonella sp dan Shigella sp) (Ratajczak et al., 2015).

\subsubsection{Pembuatan granul ekstrak buah kemukus}

Ekstrak kental yang dihasilkan diuji viskositasnya dengan alat viskosimeter. Pembuatan granul menggunakan bahan tambahan amilum sagu dan aerosil dengan perbandingan sebagai berikut seperti pada Tabel 1. Pembuatan granul dilakukan dengan mencampur ekstrak kental dengan Aerosil kemudian ditambahkan amilum sagu sedikit demi sedikit sampai diperoleh masa elastis. Massa elastis diayak menggunakan ayakan 16 mesh kemudian dikeringkan menggunakan oven pada suhu $40^{\circ} \mathrm{C}$ selama 3 jam. Granul kering kemudian dispherinisasi menggunakan ayakan 18 mesh. Granul yang diperoleh kemudian dilakukan evaluasi.

Tabel 1. Rancangan formula kapsul ekstrak kemukus dengan variasi amilum sagu dan Aerosil menggunakan factorial design.

\begin{tabular}{cccc}
\hline Rancangan Formula & Berat ekstrak kering (g) & Amilum sagu (g) & Aerosil (g) \\
\hline I (A1, A2 dan A3) & 112 & 100 & 15 \\
II (B1, B2 dan B3) & 112 & 150 & 15 \\
III (C1, C2 dan C3) & 112 & 100 & 20 \\
IV (D1, D2 dan D3) & 112 & 150 & 20 \\
\hline
\end{tabular}

\subsubsection{Uji sifat fisik granul}

Uji sifat fisik granul meliputi susut pengeringan, indeks pengetapan, sifat alir, densitas, sudut diam, daya serap dan diameter granul. Susut pengeringan dilakukan dengan alat moisuture analyzer balance. Sudut diam dan kemampuan mengalir diukur menggunakan digital flowmeter (Erweka). Densitas dan indeks pengetapan diukur menggunakan tapping device Erweka. Daya serap air diukur menggunakan alat modifikasi daya serap berbasis timbangan analitik. Hasil karakterisasi granul dianalisis menggunakan pendekatan analisis regresi linear berganda menggunakan pendekatan factorial design. Analisis statistik yang diimplementasikan pada factorial design berbasis analisis regresi linear berganda menggunakan taraf kepercayaan 95\% ( $p$-value $=0,05)$. 


\section{Hasil dan Pembahasan}

\subsection{Identifikasi buah kemukus secara makroskopi}

Identifikasi buah kemukus secara makroskopi diketahui bahwa buah berwarna hitam bertangkai dengan permukaan luar berkerut seperti anyaman jala seperti yang terlihat pada Gambar 1 (a). Buah kemukus berdiameter sekitar 0,5 cm serta memiliki bau yang khas, rasa agak pedas, dan pahit.

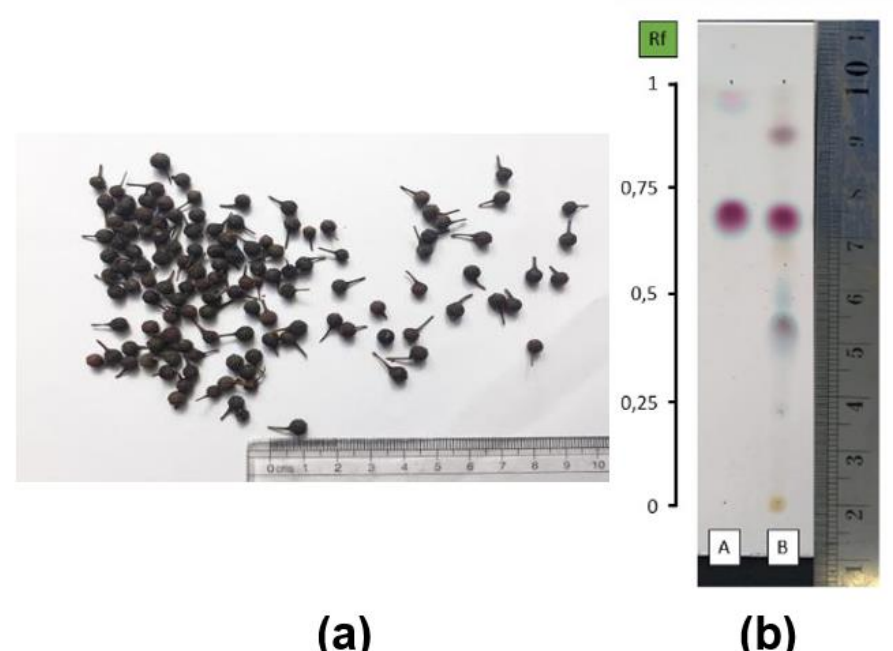

Gambar 1. Buah kemukus (Piper cubeba Lf) (a) dan profil kromatografi lapis tipis standar kubebin (A) dan ekstrak kemukus (B) menggunakan fase gerak diklorometan:etil asetat $(8: 2)$ dan fase diam silica gel $\mathrm{GF}_{245 \mathrm{~nm}}$ menggunakan deteksi asam sulfat $(5 \%)$ dalam etanol (b).

Analisis secara mikroskopi tidak dilakukan karena bahan baku diperoleh dalam bentuk simplisia utuh yang sudah dipastikan bahwa simplisia yang digunakan adalah buah kemukus (Piper cubeba Lf.). Analisis mikroskopi perlu dilakukan terhadap bahan baku herbal yang sukar diidentifikasi secara makroskopi. Buah kemukus dari Wonosobo memiliki ukuran yang relatif lebih besar dibandingkan buah kemukus dari Magelang dan Kulonprogo. Hal tersebut dipengaruhi oleh perbedaan iklim, komposisi dan komponen tanah dimana tanaman tersebut tumbuh (Balekundri \& Mannur, 2020).

\subsection{Rendemen ekstrak}

Rendemen yang dihasilkan dari pembuatan ekstrak buah kemukus secara maserasi (Tabel 2) sesuai dengan baku mutu yang dipersyaratkan oleh Farmakope Herbal Indonesia (Kementerian Kesehatan RI, 2017). Rendemen ekstrak dari ketiga tempat tumbuh memenuhi baku mutu Farmakope Herbal Indonesia, dengan hasil tertinggi adalah ekstrak buah kemukus dari Wonosobo. Jumlah rendemen tersebut menggambarkan komponen yang dapat terekstrak dari simplisia buah kemukus. Semakin tinggi rendemen komponen terekstrak semakin tinggi. Akan tetapi belum menggambarkan kandungan kubebin secara langsung 
Tabel 2. Randemen hasil ekstraksi buah kemukus dari Kulonprogo, Magelang, dan Wonosobo.

\begin{tabular}{ccc}
\hline Daerah asal & Randemen (\%) & Baku mutu (\%) \\
\hline Kulonprogo & 14,11 & $>8,2$ \\
Magelang & 9,32 & \\
Wonosobo & 19,26 & \\
\hline
\end{tabular}

\subsection{Hasil penetapan kadar kubebin ekstrak kemukus dari Kulonprogo, Magelang, dan Wonosobo}

Penetapan senyawa marker menjadi pekerjaan rutin di industri obat bahan alam oleh karena itu metode yang dipilih yaitu kromatografi lapis tipis karena relatif sederhana, simpel serta mampu memisahkan sampel secara selektif, sensitif, dan handal (Kalász \& Báthori, 2020). Identifikasi serta penetapan kadar metabolit dalam suatu ekstrak/simplisia perlu dilakukan untuk menjamin standarisasi mutu ekstrak (Marliyana et al., 2021). Skrining awal keberadaan kubebin di dalam ekstrak kemukus bisa dilihat pada Gambar 2. Bercak yang diduga sebagai kubebin berwarna merah jambu dengan hrf 67. Warna ungu muncul karena reaksi antara kubebin dengan pereaksi penampak bercak $\mathrm{H}_{2} \mathrm{SO}_{4}$ (Wagner \& Bladt, 1996). Keberadaan kubebin secara kualitatif pada ekstrak kemukus sesuai dengan baku mutu (Kementerian Kesehatan RI, 2017). Gambar 1 (b) menunjukkan bahwa bercak pada ekstrak memiliki nilai hrf yang relatif sama dengan baku mutu kubebin.

Analisis kuantitatif untuk mengukur kadar kubebin dilakukan pada ekstrak kemukus dari daerah Kulonprogo, Magelang, dan Wonosobo. Ekstrak yang telah dipreparasi dielusi dengan berbagai seri konsentrasi mutu baku kubebin pada kondisi yang sama. Hasil visualisasi plat KLT di bawah sinar UV 254 disajikan pada Gambar 2. Hasil menunjukkan bahwa kubebin dalam ketiga sampel memiliki pola hrf yang relatif sama dengan baku mutu kubebin. Selain itu, perbedaan intensitas pada sampel secara kualitatif menunjukkan perbedaan kandungan kubebin dalam sampel. Intensitas pada sampel ekstrak kemukus dari daerah Kulonprogo secara visual memiliki intensitas yang paling lemah dibandingkan sampel lainnya. Hasil KLT penunjukkan pola pemisahan bercak yang sempurna sehingga metode yang diaplikasikan memiliki spesifitas yang baik.

Plat KLT kemudian dianalisis secara densitometri sehingga diperoleh luas puncak pada nilai hrf yang sejajar dengan baku kubebin sehingga diperoleh kurva kalibrasi dan pesamaan garis regresi yang disajikan pada Gambar 3. Hasil menunjukkan bahwa kadar kubebin menunjukkan pengaruh yang bermakna terhadap peningkatan luas puncak kubebin $(p<0,05)$. Parameter goodness of fit $\left(\mathrm{R}^{2}\right.$ dan residual $\left.\left(\mathrm{S}_{\mathrm{xy}}\right)\right)$ menunjukkan bahwa model Persamaan regresi memiliki pengaruh sebesar 93,95\% dengan nilai residual 9,88\% dengan Persamaan regresi $y=934,2 x+24675$ dengan $y$ adalah luas puncak dan $x$ adalah kadar kubebin. Validasi metode analisis KLT densitometri menunjukkan bahwa linearitas yang tinggi dengan nilai 
koefisien korelasi sebesar 0,9693. Hasil analisis spesifitas berdasarkan pola pemisahan bercak ditunjukkan bahwa bercak yang identik dengan baku mutu kubebin terpisah dengan komponen lainnya. Hasil analisa presisi dilihat dari variabilitas luas puncak diperoleh nilai sebesar 7,5\% (Tabel 3). Beberapa parameter validasi tersebut menunjukkan bahwa model regresi ini valid dan reliabel untuk mengkuantifikasi kadar kubebin dalam ekstrak kemukus.

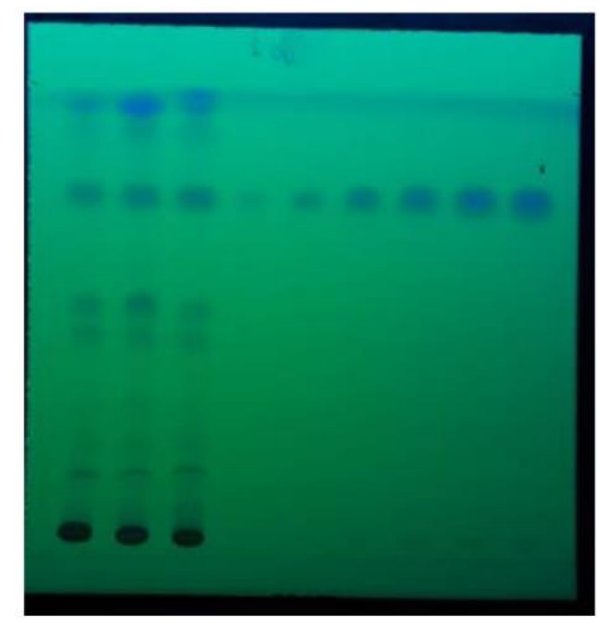

$\begin{array}{lllllllll}\text { A } & \text { B } & \text { C } & 1 & 2 & 3 & 4 & 5 & 6\end{array}$

Gambar 2. Visualisasi plat KLT ekstrak kemukus berasal dari Kulonprogo (A), Magelang (B), dan Wonosobo (c) dan variasi standar kubebin (1, 2, 3, 4, 5, dan $6 \mu \mathrm{L})(1-6)$ di bawah sinar UV $254 \mathrm{~nm}$ menggunakan fase diam silica gel GF254 dan fase gerak diklorometan:etil asetat $(8: 2)$.

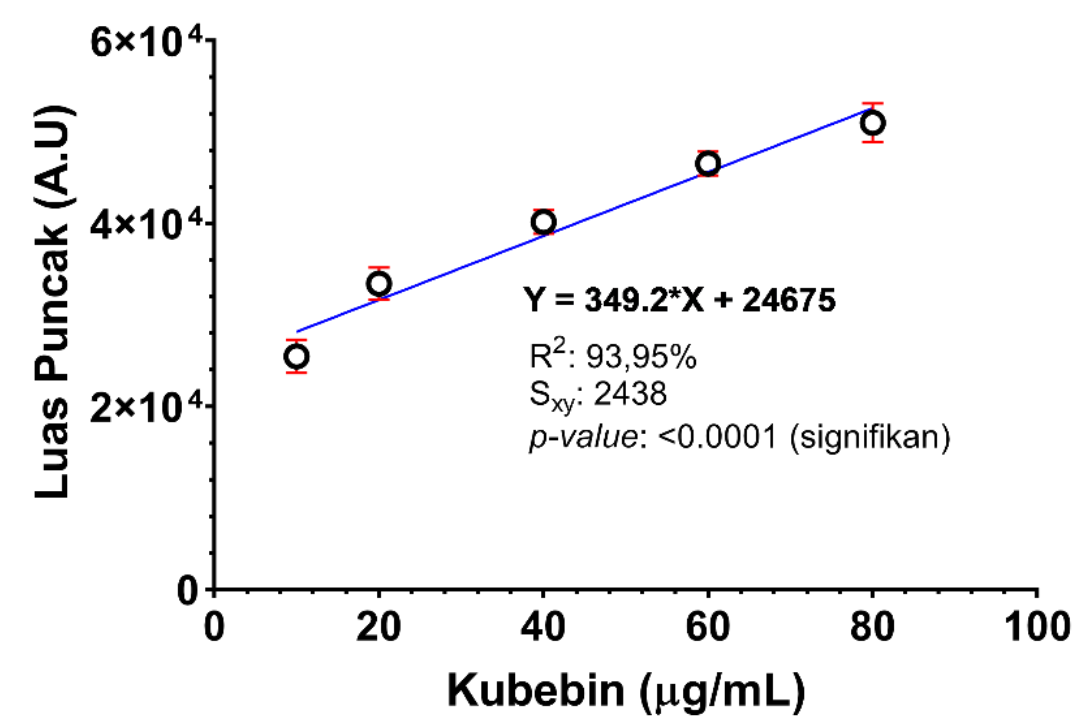

Gambar 3. Kurva kalibrasi kubebin menggunakan teknik densitometri.

Hasil pengukuran kadar kubebin pada buah kemukus dari tiga daerah bisa disajikan pada Gambar 4. Hasil kadar kubebin dalam ekstrak kemukus menunjukkan bahwa tidak ada perbedaan bermakna dari ketiga daerah ( $p>0,05)$, sehingga secara kualitatif perbedaan daerah tidak mempengaruhi kadar kubebin pada ekstrak kemukus. Akan tetapi, rendemen yang lebih 
tinggi pada ekstrak kemukus yang diperoleh dari daerah Wonosobo $(19,26 \%)$ dapat diperoleh jumlah kubebin yang lebih banyak dibandingkan dengan daerah Kulonprogo $(14,11 \%)$ dan Magelang (9,32\%).

Tabel 3. Hasil analisis presisi kubebin pada penetapan kadar kubebin dalam ekstrak kemukus.

\begin{tabular}{ccc}
\hline No & Faktor retensi (rf) & Luas puncak \\
\hline 1. & 0,74 & 31505,29 \\
2. & 0,84 & 31414,07 \\
3. & 0,79 & 37471,45 \\
4. & 0,69 & 33849,06 \\
5. & 0,64 & 34978,47 \\
\hline & Nilai Rerata & 33843,67 \\
& SD & 2540,65 \\
& CV $(\%)$ & 7,51 \\
\hline
\end{tabular}

\subsection{Standardisasi simplisia buah kemukus dari daerah Wonosobo}

Buah kemukus dari Wonosobo dipilih sebagai sumber bahan baku karena memiliki beberapa keunggulan dibandingkan buah kemukus dari Kulonprogo dan Magelang yaitu ketersediaan bahan baku, randemen ekstrak serta kadar kubebin paling tinggi. Hasil standardisasi simplisia kemukus seperti yang tertera pada Tabel 4.

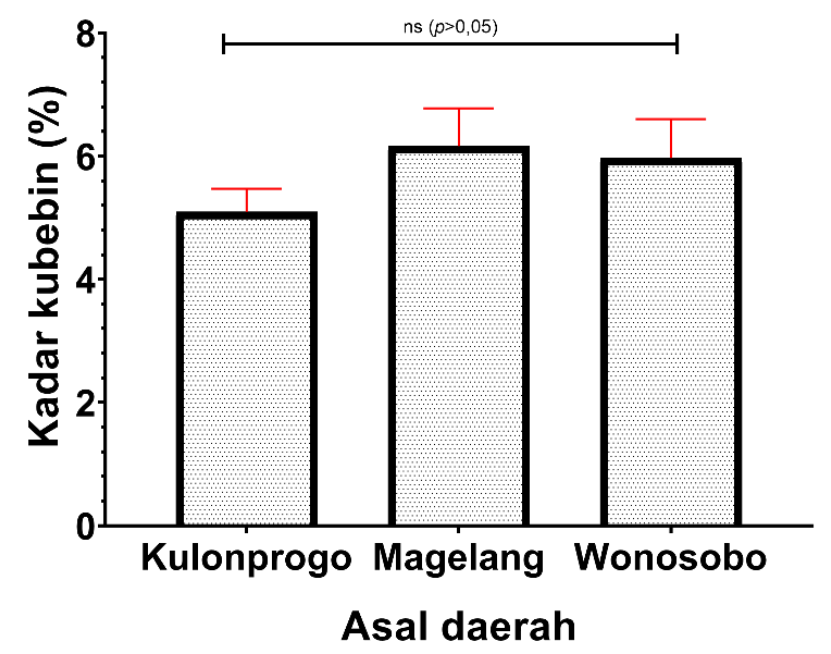

Gambar 4. Hasil penetapan kadar kubebin pada buah kemukus dari daerah Kulonprogo, Magelang dan Wonosobo. Keterangan: ns = tidak berbeda bermakna $(p>0,05)$.

Penetapan parameter non spesifik dimulai dari bahan baku simplisia sebab bahan awal yang digunakan adalah masih dalam bentuk simplisia. Berdasarkan pengujian hampir semua parameter memenuhi persyaratan kecuali susut pengeringan. Susut pengeringan menggambarkan banyaknya senyawa yang hilang selama proses pemanasan pada suhu 105 ${ }^{0} \mathrm{C}$. Kemukus kaya akan minyak atsiri, sehingga pada susut pengeringan, jumlah yang hilang bukan hanya air saja tetapi juga keberadaan minyak atsiri. Kemudian dilakukan uji kadar air untuk mengoreksi, hasil uji kadar air menunjukkan hasil yang memenuhi persyaratan. Hasil uji menunjukkan bahwa simplisia dan ekstrak buah kemukus memenuhi baku mutu 
standardisasi yang telah ditetapkan (Andayani \& Nugrahani, 2018; Departemen Kesehatan, 2000; Kementerian Kesehatan RI, 2017)

Tabel 4. Hasil penetapan parameter non spesifik simplisia buah kemukus dari Wonosobo. Keterangan: NLT-Not Less Than (tidak kurang dari) dan NMT-Not More Than (tidak lebih dari).

\begin{tabular}{llcc}
\hline No & \multicolumn{1}{c}{ Parameter } & Hasil & Syarat \\
\hline 1. & kadar minyak atsiri & $10,93 \%$ & NLT $0,75 \%$ \\
2. & Susut pengeringan & $11,33 \%$ & NMT $10 \%$ \\
3. & Kadar air & $4,43 \%$ & NMT $10 \%$ \\
4. & Kadar abu & $5,98 \%$ & NMT $8,1 \%$ \\
5. & Kadar abu tak larut asam & $0,34 \%$ & NMT $0,7 \%$ \\
6. & Cemaran logam berat & & \\
& $\mathrm{Hg}$ & Tidak terdeteksi & NMT $5 \mathrm{ppm}$ \\
& $\mathrm{Pb}$ & 0,42 ppm & NMT $10 \mathrm{ppm}$ \\
& $\mathrm{Cd}$ & Tidak terdeteksi & NMT $0,3 \mathrm{ppm}$ \\
& As & Tidak terdeteksi & NMT $0,5 \mathrm{ppm}$ \\
7. & & \\
& Oxidu pestisida & Tidak terdeteksi & NMT 0,00500 \\
& DDT & Tidak terdeteksi & NMT 0,00024 \\
& Gamma-BHC & Tidak terdeteksi & NMT 0,00300 \\
& Endosulfan II & Tidak terdeteksi & NMT 0,00200 \\
& Heptachlor & Tidak terdeteksi & NMT 0,00100 \\
Aldrin & Tidak terdeteksi & NMT 0,00170 \\
& Hexachrolbenzen & Tidak terdeteksi & NMT 0,00200 \\
Chlorothalonil & Tidak terdeteksi & NMT 0,00100 \\
4,4-DDE & Tidak terdeteksi & NMT 0,00100 \\
4,4 DDT & Tidak terdeteksi & NMT 0,00024 \\
8flatoksin total & Negatif & NMT 0,03000 \\
\hline
\end{tabular}

Kadar air simplisia kemukus bisa dikatakan rendah yaitu sebesar 4,43\%. Hal ini bisa diamati, bahwa simplisia kemukus relatif lebih awet dan tidak mudah berjamur meskipun sudah disimpan dalam kurun waktu yang lama. Kadar air mengGambarkan keberadaan air yang masih ada di dalam bahan, kadar air yang terlalu tinggi menyebabkan tanaman rentan ditumbuhi mikroba. Keberadaan air juga memicu terjadinya reaksi enzimatis yang bisa berpengaruh terhadap perubahan struktur kimia dari senyawa aktif. Kadar air pada ekstrak kemukus relatif rendah yaitu sebesar 4,33\%. Kadar air yang cukup rendah pada ekstrak membantu kondisi ekstrak tetap awet.

Kadar minyak atsiri pada simplisia sebesar $10,93 \%$ jauh lebih tinggi dari pada baku standarnya. Keberadaan minyak atsiri di dalam ekstrak kemukus ikut berperan dalam aktivitas farmakologi. Bersama dengan kubebin memiliki efek yang sinergis untuk gangguan asma (Departemen Kesehatan, 2000). Kandungan minyak atsiri yang terdapat pada buah kemukus terdiri dari golongan alkohol trisiklik sesquiterpen; 1,4-sineol, terpineol-4, kadinol dan kadinen (Wagner \& Bladt, 1996) tidak seperti minyak atsiri golongan monoterpen, alkohol 
trisiklik sesquiterpen cenderung sukar menguap dan terdapat dalam wujud seperti minyak lemak yang mudah diamati pada saat proses penguapan ekstrak. Hal ini bisa dilihat dari nilai kadar minyak atsiri yang terkandung di dalam ekstrak kemukus masih cukup tinggi yaitu $22,25 \%$. Minyak-minyak yang ada dalam ekstrak kemukus menyebabkan proses pengentalan ekstrak relatif lama dibandingkan dengan ekstrak lain.

\subsection{Standardisasi ekstrak kemukus}

Hasil standardisasi ekstrak kemukus bisa dilihat pada Tabel 5. Data yang diperoleh dibandingkan dengan monografi Farmakope Herbal Indonesia (Kementerian Kesehatan RI, 2017). Pengujian aflatoksin, residu pestisida dan logam berat, hanya dilakukan pada simplisia, karena hasil pegujian ini tidak terpengaruh oleh proses pengolahan sehingga hasil pengujian pada simplisia bisa menggambarkan hasil pada ekstrak. Sedangkan cemaran mikroba seperti angka lempeng total (ALT) dan angka kapang/khamir (AKK) serta mikroba patogen sangat dipengaruhi oleh kondisi penyimpanan dan proses pengolahan, sehingga pengujian pada simplisia tidak dilakukan. Pengujian cemaran mikroba dilakukan pada ekstrak kental dan produk jadi.

Tabel 5. Kontrol kualitas parameter standar mutu ekstrak buah kemukus dari yang dikoleksi dari Wonosobo.

\begin{tabular}{llcc}
\hline No & \multicolumn{1}{c}{ Parameter } & Hasil & Syarat \\
\hline 1. & Randemen & $22,17 \%$ & NLT $8,2 \%$ \\
2. & Kadar kubebin & $0,56 \pm 0,06 \%$ & NLT 0,93 \% \\
3. & Kadar minyak atsiri & $22,25 \%$ & NLT $1,40 \%$ \\
4. & Angka kapang/khamir & $<10$ CFU/gram & NMT $10^{3}$ CFU/gram \\
5. & Angka Lempeng total & $<10$ CFU/gram & NMT 10 $0^{4}$ CFU/gram \\
6. & Kadar air & $4,33 \%$ & NMT 10\% CFU/gram \\
7. & Mikroba patogen & Negatif & Negatif \\
& a. Escherichia coli & Negatif & Negatif \\
& b. Staphylococcus aureus & Negatif & Negatif \\
& c. Pseudomonas aeruginosa & Negatif & Negatif \\
& d. Salmonella sp & Negatif & Negatif \\
& e. Shigella sp & Negatif & Negatif \\
8. Angka kapang/khamir & $<10$ CFU/gram & NMT 10 3 CFU/gram \\
\hline
\end{tabular}

Ekstrak kental kemukus memenuhi semua parameter standar mutu yang ditetapkan Farmakope Herbal Indonesia kecuali kadar kubebin (Tabel 5). Hasil uji viskositas ekstrak kental memiliki nilai sebesar 4,41 $\pm 0,14$ dPas. Selain dilakukan uji yang mengikuti pedoman Farmakope Herbal, juga dilakukan uji cemaran mikroba karena cemaran mikroba bisa terjadi selama proses pembuatan. Hal ini mengikuti monografi parameter standar umum ekstrak tumbuhan obat (Departemen Kesehatan, 2000) dari hasil pengujian, ekstrak kental memenuhi persyaratan batas cemaran mikroba. Cemaran mikroba menjadi acuan selanjutnya ketika ekstrak akan diformulasikan menjadi bentuk sediaan, karena ada batasan minimal yang harus 
diikuti ketika produk akan diedarkan. Apabila ekstrak sudah tidak memenuhi persyaratan, maka tidak bisa dilanjutkan menjadi sediaan farmasi. Formulasi sediaan farmasi dilakukan dalam bentuk sediaan granul yang dapat diubah menjadi bentuk sediaan kapsul.

\subsection{Uji sifat fisik granul}

Granul ekstrak kemukus dievaluasi beberapa parameter yaitu susut pengeringan, indeks pengetapan, waktu alir, densitas ruah, sudut diam, dan daya serap. Hasil evaluasi berdasarkan pendekatan desain factorial dengan Teknik analisis regresi linear berganda menunjukkan bahwa variable yang dikaji yaitu komponen bahan pengisi (amilum sagu) dan bahan pengering (Aerosil; fumed silica) tidak menunjukkan pengaruh yang bermkana terhadap semua parameter sifat fisik granul $(\mathrm{p}>0,05)$ kecuali indeks pengetapan $(\mathrm{p}<0.05)$. Hasil ini disebabkan karena kontribusi dari bahan pengisi dan pengering memberikan efek minor dan tidak dominan jika dibandingkan dengan karakteristik dari ekstrak, sehingga granul yang dibentuk tidak menunjukkan perbedaan yang bermakna.

Hasil analisis terhadap parameter indeks pengetapan menggambarkan kemampuan mengalir dari granul. Hasil ini selain dipengaruhi oleh gaya tarik antarpartikel yang dipengaruhi oleh distribusi ukuran partikel dan densitas ruah dari granul ekstrak kemukus. Indeks pengetapan granul ekstrak kemukus yang diperoleh pada rentang 6,01-11,52\%. Hasil tersebut kemudian dianalisis dengan pendekatan regresi linear berganda dan diperoleh contour plot indeks pengetapan dengan Persamaan regresi linear berganda dan ilustrasi yang disajikan pada Persamaan 1 dan Gambar 5.

$$
\text { Indeks pengetapan }(\%)=9,36+0,75^{*} \mathrm{~A}-1,08 * \mathrm{~B}+0,62 * \mathrm{~A} * \mathrm{~B}
$$

Persamaan 1. Persamaan indeks pengetapan granul ekstrak kemukus menggunakan metode factorial design.

Hasil menunjukkan bahwa indeks pengetapan paling rendah (kemampuan mengalir paling bagus) diperoleh pada jumlah amilum sagu paling sedikit dengan Aerosil pada level atas. Hasil ini menunjukkan bahwa semakin tinggi konsentrasi ekstrak kemampuan mengalir akan semakin meningkat karena terbentuk granul yang lebih mampat. Peningkatan indeks pengetapan sebanding dengan peningkatan jumlah amilum sagu dan penurunan jumlah Aerosil. Beberapa contour plot dari parameter sudut diam, densitas, dan daya serap air granul ekstrak buah kemukus yang menunjukkan pengaruh tidak bermakna.

Analisa secara kualitatif granul dan ekstrak dilakukan secara KLT berbasis pada pola bercak dan identifikasi secara kualitatif senyawa kubebin. Hasil disajikan pada Gambar 6 yang menunjukkan bahwa tidak terdapat perubahan pola bercak dan intensitas bercak pada hasil KLT, sehingga menunjukkan bahwa proses granulasi tidak mempengaruhi komponen kandungan metabolit pada ekstrak buah kemukus. 


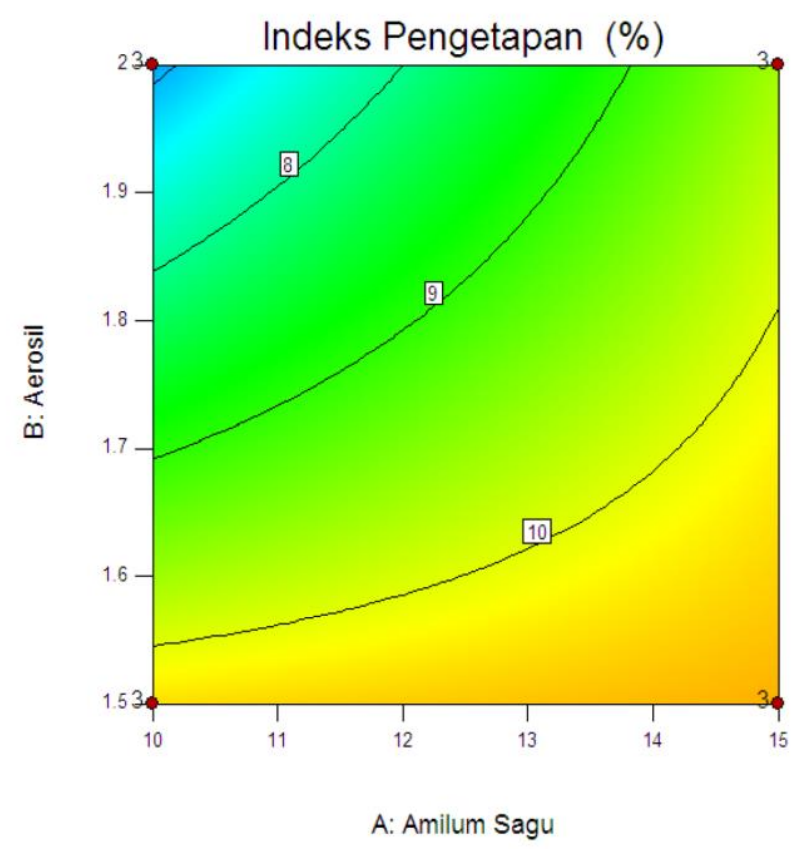

Gambar 5. Contour plot indeks pengetapan granul kemukus dengan pendekatan factorial design.

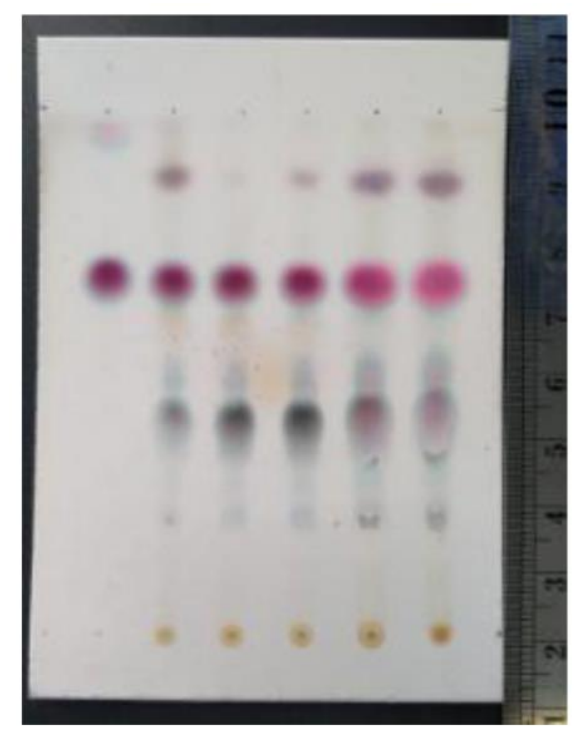

$\begin{array}{llllll}1 & 2 & \text { A } & \text { B } & \text { C } & \text { D }\end{array}$

Gambar 6. Profil kromatografi lapis tipis dari standar kubebin (1), ekstrak kemukus (2), dan 4 formula granul (A-D) dengan fase diam silica gel GF254 dan fase gerak diklorometan:etil asetat (8:2) menggunakan deteksi semprot 5\% asam sulfat dalam etanol.

\section{Kesimpulan}

Perbedaan tempat tumbuh tidak berpengaruh terhadap kadar kubebin di dalam ekstrak, tetapi berpengaruh terhadap randemen. Serta proses granulasi tidak berpengaruh pada senyawa kubebin. Hasil standardisasi kemukus dari Wonosobo menunjukkan bahwa parameter non-spesifik untuk simplisia dan ekstrak memenuhi persyaratan bahan baku obat tradisional sesuai acuan standar WHO Guidelines dan Farmakope Herbal Indonesia. Hasil uji 
sifat fisik granul meliputi susut pengeringan, indeks pengetapan, sifat alir, densitas, sudut diam, daya serap granul dan diameter granul menunjukkan bahwa granul ekstrak buah kemukus memenuhi baku mutu yang ditetapkan.

\section{Ucapan Terimakasih}

Penulis mengucapkan terima kasih kepada Direktorat Jenderal Pendidikan Tinggi atas hibah PTUPT (Penelitian Terapan Unggulan Perguruan Tinggi) serta kepada pihak-pihak yang memberikan dukungan sehingga penelitian ini dapat terselesaikan.

\section{Deklarasi Konflik Kepentingan}

Teuku Nanda Saifullah Sulaiman merupakan salah satu editorial board di JPSCR: Journal of Pharmaceutical Science and Clnical Research, akan tetapi proses evaluasi naskah ini dilakukan sesuai dengan etika publikasi dan diproses sesuai prosedur di JPCSR. Semua penulis tidak memiliki konflik kepentingan apapun terhadap hasil pada hasil penelitian ini.

\section{Daftar Pustaka}

Ahmad, H., Khera, R.A., Hanif, M.A., dan Ayub, M.A., (2020). Cubeb, dalam: Medicinal Plants of South Asia. Elsevier, hal. 149-164.

Alqadeeri, Rukayadi, Abbas, dan Shaari, (2019). Antibacterial and Antispore Activities of Isolated Compounds from Piper cubeba L. Molecules, 24: 3095.

Andayani, D. dan Nugrahani, R., (2018). Skrining Fitokimia dan Aktivitas Antioksidan Ekstrak Etanol Daun Katang-Katang (Ipomoea pescaprae. L) dari Pulau Lombok Nusa Tenggara Barat. JPSCR: Journal of Pharmaceutical Science and Clinical Research, 02 (3):76-83.

Arruda, C., Mejía, J.A.A., Pena Ribeiro, V., Costa Oliveira, L., e Silva, M.L.A., dan Bastos, J.K., (2019). Development of a Validated High-Performance Liquid Chromatography Method and Optimization of the Extraction of Lignans from Piper cubeba. Journal of Agricultural and Food Chemistry, 67: 753-759.

Bajpai, (2012). Standardization of Ethanolic Extract of Cucurbita Maxima Seed. Journal of Applied Pharmaceutical Science, 02: 92-95.

Balekundri, A. dan Mannur, V., (2020). Quality control of the traditional herbs and herbal products: a review. Future Journal of Pharmaceutical Sciences, 6: 67.

Bessaire, T., Mujahid, C., Mottier, P., dan Desmarchelier, A., (2019). Multiple Mycotoxins Determination in Food by LC-MS/MS: An International Collaborative Study 18. Toxins, 11(11), 658.

Cahyaningsih, R., Magos Brehm, J., dan Maxted, N., (2021). Gap analysis of Indonesian priority medicinal plant species as part of their conservation planning. Global Ecology and Conservation, 26: e01459.

Departemen Kesehatan, (2000). Parameter Standar Umum Ekstrak Tumbuhan Obat. Jakarta : Departemen Kesehatan RI.

Gaonkar, V.P., Hullatti, K., dan Mannur, V., (2020). Standardization of Trigonella foenumgraecum L. Seeds: A Quality by Design Approach. Indian Journal of Pharmaceutical Education and Research, 54: 1072-1079.

Kalász, H. dan Báthori, M., (2020). Chapter 10 Basis andpharmaceutical applications of thinlayer chromatography, dalam: Handbook of Analytical Separations. Elsevier, hal. 439501. 
Kementerian Kesehatan RI, (2017). Farmakope Herbal Indonesia, edisi kedua. Jakarta: Kementerian Kesehatan RI

Lim, T.K., (2012). Piper cubeba, dalam: Lim, T.K. (Editor), Edible Medicinal And NonMedicinal Plants: Volume 4, Fruits. Springer Netherlands, Dordrecht, hal. 311-321.

Lubbe, A. dan Verpoorte, R., (2011). Cultivation of medicinal and aromatic plants for specialty industrial materials. Industrial Crops and Products, 34: 785-801.

Makmun, M.T. al, Widodo, S.E., dan Sunarto, (2014). Construing Traditional Javanese Herbal Medicine of Headache: Transliterating, Translating, and Interpreting Serat Primbon Jampi Jawi. Procedia - Social and Behavioral Sciences, 134: 238-245.

Marliyana, S.D., Wartono, M.W., dan Dahlia, I. (2021). Steroid B-Sitosterol Dari Kayu Batang Slatri (Calophyllum soulattri BURM. F), JPSCR: Journal of Pharmaceutical Science and Clinical Research, 01:33-40

Masoodi, K.Z., Lone, S.M., dan Rasool, R.S., (2021). Thin layer chromatography (TLC), dalam: Advanced Methods in Molecular Biology and Biotechnology. Elsevier, hal. 143146.

Pillai, D. dan Pandita, N., (2016). Validated high performance thin layer chromatography method for the quantification of bioactive marker compounds in Draksharishta, an ayurvedic polyherbal formulation. Revista Brasileira de Farmacognosia, 26: 558-563.

Ratajczak, M., Kubicka, M.M., Kamińska, D., Sawicka, P., dan Długaszewska, J., (2015). Microbiological quality of non-sterile pharmaceutical products. Saudi Pharmaceutical Journal, 23: 303-307.

Reynolds, S. (2019). Analytical Quality Control and Method Validation Procedures for Pesticide Residues Analysis in Food and Feed. European Commision Directorate General for Health and Food Safety, SANTE/12682/2019: 52.

Salehi, B., Zakaria, Z.A., Gyawali, R., Ibrahim, S.A., Rajkovic, J., Shinwari, Z.K., Khan, T., Sharifi-Rad, J., Ozleyen, A., Turkdonmez, E., Valussi, M., Tumer, T. B., Fidalgo, L.M., Martorell, M., dan Setzer, W.N. (2019). Piper Species: A Comprehensive Review on Their Phytochemistry, Biological Activities dan Applications. Molecules, 24: 1364.

The United States Pharmacopeial Convention, (2017). Elemental Impurities-Limits. Rockville : First Supplement to USP 40-NF 35. https://www.usp.org/sites/default/files/usp/document/our-work/chemical-medicines/keyissues/232-40-35-1s.pdf.

Wagner, H., dan Bladt, S., (1996). Plant Drug Analysis: A Thin Layer Chromatography Atlas Second Edition, 248-250. Sydney : Springer Science \& Business Media.

Wahyono, (2005). Isolation dan Structure Elucidation of Tracheospasmolytic Compounds from Piper cubeba L.f Friuts and Their Possibility as Anti Inflammatory Activity, Disertasi, Yogyakarta : Universitas Gadjah Mada.

World Health Organization (Editor), (2011). Quality Control Methods for Herbal Materials, Updated edition of Quality control methods for medicinal plant materials, 1998. ed. Geneva : World Health Organization.

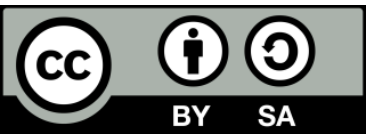

(C) 2021 by the authors. Submitted for possible open access publication under the terms and conditions of the Creative Commons Attribution-ShareAlike 4.0 International (CC BY-SA 4.0) license (https://creativecommons.org/licenses/by-sa/4.0/). 